\title{
Fermentation characteristics and inhibitory effect of brown rice vinegar on adipocyte differentiation in 3T3-L1 cells
}

\author{
Eun $\mathrm{Ah} \mathrm{Sim}{ }^{1}$, Hyeon Hwa $\mathrm{Oh}^{1}$, Do Youn Jeong ${ }^{2}$, Geun-Seoup Song ${ }^{1}$, Young-Soo Kim ${ }^{1 *}$ \\ ${ }^{1}$ Department of Food Science and Technology, Jeonbuk National University, Jeonju 54896, Korea \\ ${ }^{2}$ Microbial Institute for Fermentation Industry (MIFI), Sunchang 56048, Korea
}

\section{현미발효식초의 발효특성 및 3T3-L1 지방세포 분화억제 효과

\author{
심은아 ${ }^{1} \cdot$ 오현화 ${ }^{1} \cdot$ 정도연 $^{2} \cdot$ 송근섭 $^{1} \cdot$ 김영수 $^{1 *}$ \\ 1전북대학교 식품공학과, ${ }^{2}$ (재)발효미생물산업진흥원
}

\begin{abstract}
The brown rice vinegar was prepared by adding $10 \%$ of vinegar starter, and incubated using the strain Acetobacter pasteurianus JBA172705. The alcohol concentration of brown rice liquor was adjusted to $6 \%$, and seed vinegar was added to $10 \%$. Then, it was cultured by shaking for 16 days $\left(30^{\circ} \mathrm{C}, 120 \mathrm{rpm}\right)$. After fermentation, brown rice vinegar was extracted with $70 \%$ ethanol to evaluate the anti-obesity effect using 3T3-L1 adipocyte cells. The total acidity of brown rice vinegar increased to $6.43 \%$ after 16 days of fermentation, and acetic acid increased 15 times and succinic acid 2.5 times or more. The total phenolics and free amino acid contents decreased during the acetic acid fermentation period, and were $48.53 \mathrm{mg} \mathrm{GAE} / \mathrm{mL}$ and $18.79 \mathrm{mg} \%(\mathrm{w} / \mathrm{v})$ at the 16 th day of fermentation. At a concentration of $100 \mu \mathrm{g} / \mathrm{mL}$ of brown rice vineagar extract (BRV 16d), the lipid accumulation rate was $72.2 \%$. The leptin expression level was reduced by more than $50 \%$ according to the treatment of brown rice vinegar extract. It was confirmed that the PPAR $\gamma$ and SREBP-1c expression levels decreased at a concentration of $100 \mu \mathrm{g} / \mathrm{mL}$. As a result, brown rice vinegar is expected to be effective in anti-obesity by suppressing the expression of transcription factors that induce obesity.
\end{abstract}

Key words : brown rice vinegar, total acidity, fermentation, anti-obesity

\section{서 론}

식초의 분류에는 빙초산 또는 초산을 희석하여 만든 합성 식초와 곡류, 과실류, 주류 등을 주원료로 발효시켜 제조하는 발효식초가 있다(KFDA, 2012). 발효식초는 유기산, 향기성 분, 아미노산 등 기능성 성분뿐만 아니라, 관능적인 맛과 품 질이 우수하다고 평가되고 있다(Jeong, 2009). 국내의 식초는 주정발효식초가 대부분을 차지하고 있지만(Jeong, 2009), 발 효식품에 대한 소비자들의 인식이 높아지면서 천연과실 및
곡류 $100 \%$ 로 제조한 천연발효식초의 수요가 증가하고 있는 추세이다(Kim과 Shin, 2014). 천연발효로 제조된 곡류식초 중 현미식초는 식생활에 오래 이용된 대표적인 발효식품으로 유 기산, 당류, 아미노산, ester 등의 성분들을 함유한다(Joo 등, 2009). 또한 유기산 중 acetic acid 외에도 citric acid, oxalic acid 등 다양한 유기산과 leucine, lysine 등 아미노산을 함유 하여 영양적으로 높게 평가되어 왔다(Lee 등, 2010).

초산이 함유된 식초의 섭취는 중성지방과 콜레스테롤을 감 소시키고(Fushimi 등, 2006), AMP-activated protein kinase

*Corresponding author. E-mail : ykim@jbnu.ac.kr, Phone : +82-63-270-2569, Fax : +82-63-270-2572

Received 15 January 2021; Revised 22 March 2021; Accepted 23 March 2021.

Copyright (c) The Korean Society of Food Preservation.

This is an Open Access article distributed under the terms of the Creative Commons Attribution Non-Commercial License (http://creativecommons.org/licenses/by-nc/4.0) which permits unrestricted non-commercial use, distribution, and reproduction in any medium, provided the original work is properly cited. 
(AMPK)의 활성을 촉진하여 지방산과 스테롤의 합성을 저해 한다고 보고되었다(Kawaguchi 등, 2002). 그러나 최근 식초 의 항비만 효과에서 동일 농도의 초산을 함유하더라도 천연발 효식초가 주정식초에 비해 지방축적률 및 지방합성유전자 발 현 억제가 더 우수하였고, 천연발효에 의해 증가된 초산의 양 뿐만 아니라, 생리활성성분 및 조성비의 차이가 영향을 미치는 것으로 추정하고 있다(Son 등, 2017). 지방세포의 분화조절은 CCAAT enhancer binding protein- $\alpha(\mathrm{C} / \mathrm{EBP} \alpha)$, peroxisome proliferator-activated receptor- $\gamma(\mathrm{PPAR} \gamma)$, sterol regulatory element binding proteins(SREBP) 등의 전사인자에 의해 연 쇄반응으로 이루어지며, 중성지방의 합성과 leptin의 생성량 과 관련이 있는 것으로 알려져 있다(Kim과 Park, 2002).

본 연구에서는 현미를 원료로 하여 전통주 제조방법에 따라 현미주를 제조하고(Baek 등, 2013), Acetobacter pasteurianus $\mathrm{JBA} 172705$ 균주를 이용하여 초산발효를 진행하였다. 초산 발효기간 동안 현미발효식초의 발효특성 및 유기산과 유리아 미노산의 함량변화를 분석하여 품질평가를 하였다. 또한, 제 조된 현미발효식초의 항비만 효과를 평가하고자 현미식초를 에탄올로 추출하여 동결건조하였다. 현미식초 추출물은 마우 스 유래 3T3-L1 지방 전구세포를 이용하여 지질축적률, 지방 세포 분화조절 유전자의 발현 및 leptin 생성량에 미치는 영 향을 분석하였다. 이와 같은 연구결과는 현미식초 제조에 적 합한 초산균주의 발굴과 in vitro 상에서 현미식초의 항비만 평가에 대한 기초자료가 될 것이라 기대된다.

\section{재료 및 방법}

\section{재료 및 시약}

본 연구에서 현미식초 제조에 사용된 현미는 우렁눈쌀 (Sunchang, Korea), 누룩은 소율곡(Gwangju, Korea) 제품을 사용하였으며, 균주 배양에 사용된 시약은 $\mathrm{BD}$ 사(Becton, Dickinson \& Co., Franklin Lakes, NJ, USA) 분석용 시약은 Sigma-Aldrich Co.(St. Louis, MO, USA) 제품을 사용하였다. 세포실험에 사용된 배지는 Gibco BRL(Grand Island, NY, USA) 제품을 dimethyl sulfoxide(DMSO), epigallocatechin gallate(EGCG), Oil-Red-O solution, IBMX, insulin from bovine pancreas, dexamethasone, rosiglitazone, 2-propanol은 Sigma사(Sigma-Aldrich Co.) 제품을 사용하였다. 세포생존율 측정을 위해 cell counting kit-8(CCK-8, Dojindo Molecular Technologies, Inc., Rockville, MD, USA)을 사용하였다. 렙 틴 정량에는 Quantikine ELISA mouse/rat leptin immunoassay kit(R\&D systems, Inc., Minneapolis, MN, USA) 제품을 RNA 추출과 cDNA 합성에는 각각 RNeas mini kit(Qiagen, Hilden, Germany), GoScript ${ }^{\mathrm{TM}}$ Reverse Transcription system
(Promega, Medison, WI, USA) 제품을 사용하였다. 그 밖의 시약들은 HPLC grade를 사용하였다. 또한, 품질 분석에서 $\mathrm{pH}$ 는 $\mathrm{pH}$ meter(PP-20, Sartorius, Göttingen, Germany), 수용 성 고형분 함량은 당도계(PAL-1, Atago Co., Tokyo, Japan), 색도는 색도계(CR 400, Konica Minolta, Tokyo, Japan)를 사 용하여 측정하였다.

\section{현미발효주 제조}

현미발효주는 Baek 등(2013)의 방법을 변형하여 제조하였 다. 증자한 현미에 누룩을 $10: 1$ 의 비율로 혼합하여 현미혼합물 을 제조하였다. (재)발효미생물산업진흥원(Microbial Institute for Rermentation Industry(MIFI), Sunchang, Korea)에서 분 양받은 Saccharomyces cerevisiae(SRCM102596)를 진탕배 양 $\left(30^{\circ} \mathrm{C}, 120 \mathrm{rpm}, 3\right.$ 일 $)$ 하여 효모배양액을 제조하였고, 현미 혼합물에 $5 \%(\mathrm{v} / \mathrm{w})$ 접종하였다. 멸균수를 이용하여 최종부피 가 $1.3 \mathrm{~L}$ 가 되도록 조절한 후 균질화하여 정치배양 $\left(30^{\circ} \mathrm{C}, 6\right.$ 일)하였다. 제조된 현미발효주에 멸균수를 첨가하여 알코올 함량이 $6 \%$ 가 되도록 조정하였고, 이를 원심분리 $(10,000 \times g$, $4^{\circ} \mathrm{C}, 10$ 분)하여 고형분을 제거한 상등액을 현미식초 제조에 사용하였다.

\section{현미발효식초 제조}

현미발효식초는 Lee 등(2018)의 방법을 변형하여 제조하 였다. 환류냉각관을 부착한 수기에 현미발효주 상등액을 취 해 $85^{\circ} \mathrm{C}$ 의 항온수조에서 30 분간 열처리하여 효모를 불활성화 시킨 후 냉각하여 현미주로 하였다. 선행연구 $(\operatorname{Sim}, 2020)$ 를 통해 선발된 초산균 A. pasteurianus JBA172705(Acetobacter pasteurianus (T) LMD 1591와 98.7\% 일치)를 GYE broth ( $1 \%$ yeast extract, $5 \%$ glucose, $6 \%$ ethanol)에 1 백금이 접종 하고 진탕배양 $\left(30^{\circ} \mathrm{C}, 120 \mathrm{rpm}, 3\right.$ 일)하여 전배양한(Shim, 2020) 후에 현미주에 전배양액을 $1 \%$ 접종하고, 진탕배양 $\left(30^{\circ} \mathrm{C}, 120\right.$ $\mathrm{rpm}, 3$ 일)하여 종초로 사용하였다. 종초 $(7.50 \log \mathrm{CFU} / \mathrm{mL})$ 를 현미발효주에 $10 \%(\mathrm{v} / \mathrm{v})$ 첨가하여 진탕배양 $\left(30^{\circ} \mathrm{C}, 120 \mathrm{rpm}\right)$ 하였고, 배양기간 동안 4 일 간격으로 샘플링하여 총산도를 측정하였다. 대조구는 초산균배양 첨가 후 0 일차 시료로 하 였고, 총산도가 $6 \%$ 이상에 도달하였을 때 배양을 종결하였 다. 각 시료구는 원심분리 후에 상등액을 취해 냉동( $\left(-20^{\circ} \mathrm{C}\right)$ 에 서 보관하면서 차후 실험에 사용하였다.

\section{이화학적 특성 분석}

$\mathrm{pH}$ 는 $\mathrm{pH}$ meter를 사용하여 측정하였으며, 총산도는 시료 $1 \mathrm{~mL}$ 에 $0.1 \mathrm{~N} \mathrm{NaOH}$ 를 첨가하여 $\mathrm{pH}$ 8.3에 도달할 때까지 소모된 양을 acetic acid 함량으로 산출하였다. 수용성 고형분 함량은 당도계로 측정하였고, 색도는 시료를 일정량 취해 색 
도계를 이용하여 $\mathrm{Y}=85.6, \mathrm{x}=0.3172, \mathrm{y}=0.3241$ 인 표준 백색 판(standard white plate)으로 보정하여 $\mathrm{L}^{*}, \mathrm{a}^{*}$ 및 $\mathrm{b}^{*}$ 값을 측 정하였다. 갈변도는 분광광도계(UV-1601, Shimadzu, Kyoto, Japan)를 이용하여 $420 \mathrm{~nm}$ 에서 흡광도를 측정하여 비교하 였다.

총페놀성 화합물 함량(total phenolic content, TPC)은 ISO 14502-1(2005)의 방법을 이용하여 측정하였다. 시료 $1 \mathrm{~mL}$ 에 $10 \%$ Folin-Ciocalteu's phenol reagent $5 \mathrm{~mL}$ 를 첨가하여 3분 간 반응시킨 후에 $7.5 \% \mathrm{Na}_{2} \mathrm{CO}_{3} 4 \mathrm{~mL}$ 를 첨가하였다. 이 반 응액을 암소에서 반응 $\left(23^{\circ} \mathrm{C}, 1\right.$ 시간 $)$ 시킨 후에 분광광도계 (Shimadzu)를 이용하여 $765 \mathrm{~nm}$ 에서 흡광도를 측정하였으며, 총페놀성 화합물 함량은 gallic acid를 표준물질로 하여 시료 $\mathrm{mL}$ 당 $\mathrm{mg}$ gallic acid로 나타내었다. 정량분석에 사용된 검량 회귀식은 $\mathrm{Y}=0.0105 \mathrm{X}+0.0033\left(\mathrm{R}^{2}=0.99\right)$ 로 gallic acid 농도별 흡광도 값의 결과에서 산출하여 나타내었다.

\section{유기산 함량 분석}

유기산은 Kim과 Song(2002)의 방법을 이용하여 측정하였 다. 시료를 희석하여 $0.22 \mu \mathrm{m}$ membrane filter(Futexs Co Ltd., Daejeon, Korea)로 여과하여 HPLC system(Waters e2695, Milford, MA, USA)으로 분석하였다. HPLC system 의 분석조건은 Aminex HPX87H Ion Exclusion column (300×7.8 mm, $9 \mu \mathrm{m}$, Bio-Rad Labs., Richmond, CA, USA), 이동상은 $0.008 \mathrm{~N} \mathrm{H}_{2} \mathrm{SO}_{4}$, 유속은 $0.6 \mathrm{~mL} / \mathrm{min}$, column oven 온도는 $35^{\circ} \mathrm{C}$ 및 검출기는 photodiode array detector(Waters) 이었고, 검출 파장은 $210 \mathrm{~nm}$ 였다. 표준물질로는 oxalic acid, citric acid, tartaric acid, malic acid, succinic acid, lactic acid, acetic acid를 사용하였으며, 분리된 유기산의 각 peak 는 동일조건에서 분석한 표준물질 mixture의 peak 면적 비율 과 retention time을 비교하여 함량을 산출하였다.

\section{유리아미노산 분석}

유리아미노산은 Lee 등(2010)의 방법을 이용하여 측정하 였다. 시료는 $0.12 \mathrm{~N}$ sample dilution buffer( $\mathrm{pH}$ 2.20)로 10배 희석하여 $0.22 \mu \mathrm{m}$ membrane filter(Futexs Co., Ltd.)로 여과 하였다. 유리아미노산 분석조건은 amino acid analyzer(S433, SYKAM, Eresing, Germany)를 사용하여 분석하였다. 분석 용매인 buffer의 flow rate $0.45 \mathrm{~mL} / \mathrm{min}$, ninhydrin solution flow rate $0.35 \mathrm{~mL} / \mathrm{min}$ 이었고, 검출파장은 $440 \mathrm{~nm}$ (proline) 및 $570 \mathrm{~nm}$ 였으며, injection volume은 $100 \mu \mathrm{L}$ 였다.

\section{세포 평가를 위한 현미식초 추출물 제조}

세포실험을 위한 추출물을 제조하기 위하여 초산발효가 완료된 발효 16 일차와 대조구인 발효 0 일차 시료의 원심분리
상등액을 동결건조기(FD, Ilshin Lab Co., Ltd., Dongducheon, Korea)로 건조하였다. 건조물에 $70 \%$ 에탄올을 100 배 $(\mathrm{w} / \mathrm{v})$ 첨가하여 상온에서 4 시간 동안 교반추출한 후 원심분리 $\left(4^{\circ} \mathrm{C}\right.$, $10,000 \times g, 10$ 분)하여 상등액을 취하였다. $45^{\circ} \mathrm{C}$ 항온수조 (TW-PC-1, Universal Scientific Industrial Co., Ltd., Shanghai, China)에서 회전감압농축기(Eyela coolace CCA-110, Tokyo Rikakikai Co., Ltd., Japan)를 사용하여 에탄올을 제거한 후 소량의 증류수로 추출물을 회수하여 동결건조하였다. 발효 16 일차 현미식초 추출건조물(BRV 16d)과 발효 0 일차 대조 구 추출건조물(BRV $0 \mathrm{~d})$ 은 각각 $10 \% \mathrm{DMSO}$ 에 용해시켜 차 후 세포실험에 사용하였다.

\section{세포배양 및 지방세포 분화 유도}

실험에 사용한 mouse 유래 3T3-L1 preadipocyte은 한국세 포주은행(KCLB, Seoul, Korea)에서 분양받아 사용하였다. 3T3-L1은 10\% bovine calf serum(BCS), 1\% antibiotics (streptomycin/penicillin)이 함유된 Dulbecco's modified Eagle's medium(DMEM)을 이용하여 배양시켰다. 3T3-L1의 분화를 유도하기 위해 $1 \times 10^{5}$ cells/well의 농도로 24-well plate에 분주하여 완전한 confluent 상태가 될 때까지 배양하 였다. 이후 $10 \%$ fetal bovine serum(FBS), $1 \%$ antibiotics가 함유된 $\mathrm{DMEM}$ 배지로 교체하고, 분화유도제인 $\mathrm{MDI}(0.5$ $\mathrm{mM}$ IBMX, $1 \mu \mathrm{M}$ dexamethasone, $1 \mu \mathrm{g} / \mathrm{mL}$ insulin, $2 \mu \mathrm{M}$ rosiglitazone)와 각 농도의 시료를 함께 처리하였다. 분화유 도 48 시간 후 $10 \% \mathrm{FBS}$ 가 함유된 DMEM으로 배지를 교체 하고, $1 \mu \mathrm{g} / \mathrm{mL}$ insulin을 처리한 후 48시간 배양하였다. 이후 48시간 간격으로 $10 \% \mathrm{FBS}$ 가 함유된 DMEM으로 배지를 교 체하여 배양하였으며, 분화유도는 유도 8 일 경과 후에 확인 하였다. 양성대조구로는 $\mathrm{EGCG}(100 \mu \mathrm{M})$ 를 사용하였다.

\section{세포생존율 측정}

3T3-L1 지방전구세포는 $5 \times 10^{3}$ cells/well의 농도로 96well plate에 분주하고, $37^{\circ} \mathrm{C}, 5 \% \mathrm{CO}_{2}$ 로 조정된 incubator에 서 24시간 동안 배양한 후 시료를 농도별로 처리하였다. 48 시간 후 배지를 제거하고 PBS $100 \mu \mathrm{L}$ 와 CCK-8 solution 10 $\mu \mathrm{L}$ 를 첨가하여 암실의 incubator에서 2시간 동안 반응하였 다. 반응 후 microplate reader(US/Eon, BioTek Instruments, Inc., Winooski, VT, USA)를 사용하여 $450 \mathrm{~nm}$ 에서 흡광도 를 측정하여 세포생존율은 대조군의 흡광도 값에 대한 각 시 료첨가구의 흡광도 값을 백분율로 계산하여 나타내었다.

\section{Oil-Red-O 염색 및 지질축적률 측정}

3T3-L1의 지방분화 정도를 확인하기 위해 Zebisch 등 (2012)의 방법을 변형하여 Oil-Red-O staining을 실시하였다. 
3T3-L1 세포를 Dulbecco's phosphate buffered saline(DPBS) 로 세척하고, $4 \%$ para formaldehyde로 30 분간 고정하였다. 고정된 세포는 DPBS로 세척 후 $60 \%$ isopropyl alcohol을 5 분간 처리하고 충분히 건조하였다. 이후 Oil-Red-O 시약을 첨가하여 20분간 염색하였고, 증류수로 수회 세척하여 현미 경(TCM400, Labo America. Inc., Fremont, OH, USA)으로 분화된 세포의 사진을 촬영하였다. 마지막으로 증류수를 제 거한 후 완전히 건조시키고, isopropyl alcohol로 Oil-Red-O 을 30분 동안 용출시켜 microplate reader(BioTek)를 이용하 여 $500 \mathrm{~nm}$ 에서 흡광도를 측정하였다.

\section{렙틴 농도 측정}

렙틴의 농도는 Quantikine ELISA mouse/rat leptin immunoassay kit를 사용하여 측정하였다. 분화된 3T3-L1 세 포의 배양상층액과 assay diluent RD1W을 혼합하여 2시간 동안 상온에서 반응하였다. 이후 wash buffer로 5회 세척한 후 Mouse/Rat leptin conjugate를 첨가하여 상온에서 2시간 반 응하였다. 다시 wash buffer로 5회 세척하고 substrate solution 을 첨가하여 암소의 상태에서 30 분간 반응 후 stop solution을 첨가하여 반응을 종결하였다. 반응 종결 후 microplate reader (BioTek)를 이용하여 $450 \mathrm{~nm}$ 에서 흡광도를 측정하였다. 렙 틴 농도는 kit내의 leptin standard를 사용하여 검량선을 그려 정량하였다.

\section{역전사 유전자 중합효소 연쇄반응(reverse transcription polymerase chain reaction, RT-PCR) 분석}

$3 \mathrm{~T} 3-\mathrm{L} 1$ 세포$\left(1 \times 10^{6}\right.$ cells/well)를 6-well plate에 분주하고, 분화유도와 동일한 조건에서 배양하였다. 지방세포는 Qiagen RNeasy mini kit를 사용하여 total RNA를 분리하였고, microplate reader(BioTek)의 Take3 micro-volume plates를 사용하여 정량하였다. 이후 GoStript ${ }^{\mathrm{TM}}$ Reverse Transcription system을 사용하여 cDNA를 합성하였다. 합성된 $\mathrm{cDNA}$ 와 $\mathrm{PPAR} \gamma, \mathrm{SREBP}-1 \mathrm{c}$ primer을 각각 혼합하여 $\mathrm{PCR}$ 을 진행하 였다. 반응물은 1\% agarose gel(Lonza, Basel, Swiss)에 전기
영동하여 UV transilluminator(WUV-L50, Daihan science, Wonju, Korea)로 발현정도를 확인하였다. 유전자 발현 분석의 internal control로는 housekeeping gene인 glyceraldehydes3-phosphate dehydrogenase(GAPDH)를 사용하였으며, 실험 에 사용한 primer의 염기 서열은 Table 1과 같다. PCR 조건 은 초기변성 $95^{\circ} \mathrm{C} 3$ 분 후 denaturation $\left(95^{\circ} \mathrm{C}, 30\right.$ 초 $) \rightarrow$ annealing $\left(60^{\circ} \mathrm{C}, 30\right.$ 초 $) \rightarrow \operatorname{polymerization}\left(72^{\circ} \mathrm{C}, 30\right.$ 초 $)$ 를 30 cycle을 진행하였고, $72^{\circ} \mathrm{C}$ 에서 5 분간 처리하여 종결하였다.

\section{통계처리}

각 실험에서 얻은 결과는 SPSS package program(Ver.12.0 SPP Inc., Chicago, IL, USA)을 사용하여 평균과 표준편차로 나타내었다. 각 시료간의 유의성은 $\mathrm{p}<0.05$ 수준에서 one-way ANOVA로 분산분석한 후에 Duncan's multiple range test로 비교하였다.

\section{결과 및 고찰}

\section{현미발효식초의 발효특성}

현미발효식초의 발효특성은 현미주에 $10 \%$ 종초를 첨가한 후 진탕배양 $\left(30^{\circ} \mathrm{C}, 120 \mathrm{rpm}, 16\right.$ 일 $)$ 하며 4일 간격으로 샘플링 하여 분석하였으며, 그 결과는 Table 2 와 같다. 현미주의 $\mathrm{pH}$, 고형분량, 총산도는 각각 $4.12,4.90{ }^{\circ} \mathrm{Brix}, 0.32 \%$ 였으며, 발 효 0 일차 $\mathrm{pH}$ 는 3.87 에서 발효 16 일차에 2.94 로 감소하였고, 고형분량은 발효초기 $4.90{ }^{\circ} \mathrm{Brix}$ 에서 발효기간의 증가에 따 라 증가하여 발효 16 일차에 $5.25{ }^{\circ} \mathrm{Brix}$ 를 나타내었다. 총산도 는 첨가된 종초의 영향으로 발효 0 일차에 $0.51 \%$ 를 나타내었 으며, 발효기간이 증가함에 따라 유의적으로 증가하여 발효 종결점인 발효 16 일차에는 $6.43 \%$ 로 분석되었다. 특히, 본 연 구에서 현미주의 알코올 함량을 $6 \%$ 로 조정하여 종초를 $10 \%$ 첨가하였을 때 현미발효식초의 초기 알코올 농도는 약 $5.4 \%$ 로 감소하였으며, 발효 16 일차 현미발효식초의 총산도는 $6.43 \%$ 로 분석되었기 때문에 에탄올의 초산으로의 산화가 $100 \%$ 이상 진행된 것으로 판단된다. 이는 Lee 등(2011)의 연

Table 1. The primer sequence used for RT-PCR

\begin{tabular}{clll}
\hline Primer & \multicolumn{1}{c}{ Target gene } & Direction & \multicolumn{1}{c}{ Primer sequence (5'-3') } \\
\hline \multirow{2}{*}{ PPAR- $\gamma$} & Peroxisome proliferator-activated receptor $\gamma$ & Forward & TCGCTGATGCACTGCCTATG \\
& & Reverse & GAGAGGTCCACAGAGCTGATT \\
\hline \multirow{2}{*}{ SREBP-1c } & Sterol regulatory element-binding protein-1c & Forward & AGCAGCCCCATGAACAAACAC \\
& & Reverse & CAGCAGTAGGTCTGCCTTGAT \\
\hline \multirow{2}{*}{ GAPDH } & Glyceraldehyde 3-phosphate dehydrogenase & Forward & CGGAGTCAACGGATTTGGTCGTAT \\
& & Reverse & AGCCTTCTCCATGGTGGTGAAGAC \\
\hline
\end{tabular}


Table 2. Fermentation characteristics of brown rice vinegar with different fermentation periods

\begin{tabular}{|c|c|c|c|c|c|}
\hline \multirow{2}{*}{ Physicochemical properties } & \multicolumn{5}{|c|}{ Fermentation time (day) } \\
\hline & 0 & 4 & 8 & 12 & 16 \\
\hline $\mathrm{pH}$ & $3.87 \pm 0.01^{1) \mathrm{e} 2)}$ & $3.36 \pm 0.04^{\mathrm{d}}$ & $3.12 \pm 0.01^{\mathrm{c}}$ & $3.04 \pm 0.04^{b}$ & $2.94 \pm 0.01^{\mathrm{a}}$ \\
\hline Soluble solids $\left({ }^{\circ}\right.$ Brix $)$ & $4.90 \pm 0.00^{\mathrm{a}}$ & $5.05 \pm 0.07^{\mathrm{b}}$ & $5.10 \pm 0.00^{\mathrm{b}}$ & $5.20 \pm 0.00^{c}$ & $5.25 \pm 0.07^{\mathrm{c}}$ \\
\hline Total acidity (\%) & $0.51 \pm 0.05^{\mathrm{a}}$ & $2.15 \pm 0.12^{\mathrm{b}}$ & $3.86 \pm 0.09^{\mathrm{c}}$ & $4.96 \pm 0.30^{\mathrm{d}}$ & $6.43 \pm 0.21^{\mathrm{e}}$ \\
\hline Total phenolic content (mg GAE/mL) & $50.39 \pm 0.07^{\mathrm{b}}$ & $48.63 \pm 0.49^{\mathrm{a}}$ & $48.48 \pm 0.14^{\mathrm{a}}$ & $48.48 \pm 0.69^{\mathrm{a}}$ & $48.53 \pm 0.49^{\mathrm{a}}$ \\
\hline \multirow{3}{*}{ Color $^{3)}$} & $24.28 \pm 0.01^{\mathrm{e}}$ & $23.71 \pm 0.01^{\mathrm{c}}$ & $23.38 \pm 0.03^{\mathrm{a}}$ & $23.62 \pm 0.01^{\mathrm{b}}$ & $24.02 \pm 0.01^{\circ}$ \\
\hline & $0.12 \pm 0.00^{\mathrm{a}}$ & $0.17 \pm 0.02^{\mathrm{a}}$ & $0.16 \pm 0.03^{\mathrm{a}}$ & $0.16 \pm 0.04^{\mathrm{a}}$ & $0.18 \pm 0.01^{\mathrm{a}}$ \\
\hline & $1.17 \pm 0.00^{\mathrm{a}}$ & $1.44 \pm 0.01^{\mathrm{d}}$ & $1.46 \pm 0.02^{\mathrm{d}}$ & $1.36 \pm 0.00^{\mathrm{c}}$ & $1.22 \pm 0.01^{\mathrm{b}}$ \\
\hline Browning intensity (420 nm) & $0.17 \pm 0.00^{\mathrm{a}}$ & $0.19 \pm 0.01^{\mathrm{a}}$ & $0.19 \pm 0.00^{\mathrm{ab}}$ & $0.19 \pm 0.01^{\mathrm{ab}}$ & $0.22 \pm 0.02^{\mathrm{b}}$ \\
\hline
\end{tabular}

${ }^{1)}$ Values are mean \pm SD $(n=3)$.

${ }^{2)}$ Different small letters $\left({ }^{\mathrm{a}-\mathrm{e}}\right)$ in the same row indicate a significant difference according to Duncan's multiple test $(\mathrm{p}<0.05)$.

${ }^{3)} \mathrm{L}^{*}, \mathrm{a}^{*}$ and $\mathrm{b}^{*}$ mean the degrees of lightness, redness, and yellowness, respectively.

구에서 알코올 함량을 $6 \%$ 로 조절한 현미알코올 발효액에 종 초를 $10 \%$ 첨가하여 제조한 현미식초의 발효특성과 유사한 수준이었다. 식초의 품질규격은 초산 함량기준 4.0-20.0\% (w/v)이며(KFDA, 2012), 발효 8일 이후 $4 \%$ 이상에 도달했 을 것으로 추정되나, 잔류하는 알코올의 양을 최소화하고 발 효 16 일차까지 지속적인 총산도의 증가가 확인되었기 때문 에 최종 발효 완료시점을 16 일로 하였다.

현미발효식초의 총페놀성 화합물은 발효 초기 $50.39 \mathrm{mg}$ $\mathrm{GAE} / \mathrm{mL}$ 에서 발효가 진행됨에 따라 감소하여 발효 16 일차에 는 $48.53 \mathrm{mg} \mathrm{GAE} / \mathrm{mL}$ 를 나타내었는데, 이는 산화반응에 의 한 페놀성 화합물의 감소 때문으로 판단된다. 색도는 발효 4
일경과 후부터 redness와 yellowness가 소폭 증가하였고, 갈색 도는 16 일차 발효물에서 흡광도가 0.05 수준 증가하였다. 이와 같은 색도와 갈색도의 증가는 초산발효기간 중 알코올의 산화 반응과 현미주에 존재하는 아미노산과 환원당의 Maillard 반 응에 의해 현미식초의 갈변화가 일어나는 것으로 추정된다.

\section{현미발효식초 유기산 및 유리아미노산 함량}

현미발효식초의 발효기간에 따른 유기산 변화는 Table 3 과 같다. 현미발효식초의 발효 전 유기산의 종류와 함량은 lactic acid, acetic acid, succinic acid, tartaric acid, oxalic acid, malic acid 순으로 확인되었다. 대부분의 유기산은 초산

Table 3. Organic acid contents of brown rice vinegar with different fermentation periods

$(\mathrm{mg} \%(\mathrm{w} / \mathrm{v}))$

\begin{tabular}{|c|c|c|c|c|c|}
\hline \multirow{2}{*}{ Organic acid } & \multicolumn{5}{|c|}{ Fermentation time (day) } \\
\hline & 0 & 4 & 8 & 12 & 16 \\
\hline Oxalic acid & $5.43 \pm 0.38^{1) b 2)}$ & $4.65 \pm 0.55^{\mathrm{ab}}$ & $4.26 \pm 0.00^{\mathrm{a}}$ & $4.26 \pm 0.00^{\mathrm{a}}$ & $4.26 \pm 0.00^{\mathrm{a}}$ \\
\hline Citric acid & $\mathrm{ND}^{3)}$ & ND & ND & ND & ND \\
\hline Tartaric acid & $27.15 \pm 0.35^{\mathrm{a}}$ & $26.71 \pm 0.21^{\mathrm{a}}$ & $26.20 \pm 0.43^{\mathrm{a}}$ & $30.20 \pm 2.15^{\mathrm{b}}$ & $30.92 \pm 0.21^{\mathrm{b}}$ \\
\hline Malic acid & $1.79 \pm 0.50^{\mathrm{a}}$ & $10.10 \pm 0.49^{\mathrm{b}}$ & $11.20 \pm 0.46^{\mathrm{b}}$ & $13.21 \pm 2.09^{\mathrm{b}}$ & $12.73 \pm 2.77^{\mathrm{b}}$ \\
\hline Succinic acid & $60.68 \pm 4.07^{\mathrm{a}}$ & $64.19 \pm 1.74^{\mathrm{a}}$ & $65.35 \pm 3.21^{\mathrm{a}}$ & $82.59 \pm 8.35^{\mathrm{a}}$ & $154.30 \pm 56.80^{\mathrm{b}}$ \\
\hline Lactic acid & $509.22 \pm 28.84^{\mathrm{b}}$ & $324.79 \pm 13.40^{\mathrm{a}}$ & $299.24 \pm 1.78^{\mathrm{a}}$ & ND & ND \\
\hline Acetic acid & $416.09 \pm 8.89^{\mathrm{a}}$ & $2,595.84 \pm 15.85^{\mathrm{b}}$ & $3,472.96 \pm 29.21^{\mathrm{c}}$ & $5,055.54 \pm 448.33^{d}$ & $6,532.95 \pm 73.51^{\mathrm{e}}$ \\
\hline Total & $1,017.34 \pm 24.25^{\mathrm{a}}$ & $3,026.29 \pm 5.44^{\mathrm{b}}$ & $3,879.22 \pm 26.89^{\mathrm{c}}$ & $5,257.52 \pm 509.38^{d}$ & $6,663.46 \pm 67.72^{\mathrm{e}}$ \\
\hline
\end{tabular}

${ }^{1)}$ Values are mean \pm SD $(\mathrm{n}=3)$.

${ }^{2)}$ Different small letters $\left({ }^{\mathrm{a}-\mathrm{e}}\right)$ in the same row indicate a significant difference according to Duncan's multiple test $(\mathrm{p}<0.05)$.

${ }^{3)} \mathrm{ND}$ is an abbreviation for not detected. 
발효가 진행되면서 증가하는 경향을 보였으나, lactic acid는 발효 0 일 $506.22 \mathrm{mg} \%$ 를 나타내었으나, 발효기간에 따라 감 소하여 발효 12 일차부터 검출되지 않았다. 이는 현미주에 존 재하던 lactic acid가 초산발효과정 중 감소한 것으로 판단된 다. 특히, 곡류식초에서 lactic acid의 함량이 높으면 군냄새의 원인이 되는 것으로 알려져 있어, 초산발효에 의한 lactic aicd 의 감소는 식초의 풍미를 향상시킬 것으로 기대된다(Jeong과 Lee, 2000). Acetic acid는 발효 0일 $416.09 \mathrm{mg} \%$ 에서 발효기 간의 증가에 따라 유의적으로 증가하였으며, 발효 16 일에 $6,532.95 \mathrm{mg} \%$ 로 분석되어 약 15.7 배의 증가를 나타내었다. TCA cycle의 중간물질로서 세포의 물질대사와 기능을 조절 하는 것으로 알려져 있는 succinic acid는 발효 0 일 60.68 $\mathrm{mg} \%$ 에서 발효 12 일에 증가하기 시작하여 발효 16 일에는 $154.30 \mathrm{mg} \%$ 로 분석되었다. Tartaric acid는 발효 전 27.15 $\mathrm{mg} \%$ 에서 발효 16 일에 $30.92 \mathrm{mg} \%$ 로 증가하였다. 과일의 신
맛에 기여하며 풍미를 향상시키는 유기산인 malic acid는 발 효 0 일 $1.79 \mathrm{mg} \%$ 에서 발효 16 일에 $12.73 \mathrm{mg} \%$ 로 증가하였 다. 한편, oxalic acid는 발효에 따라 소량 감소하는 경향을 보였으나, 발효 4 일 이후에는 유의적인 차이를 보이지 않았 고, 쌀식초에서 검출되는 것으로 보고된 citric acid는 현미주 및 현미발효식초에서 분석되지 않았다. 이와 같은 유기산의 변화는 정치와 속성 발효조건에 따른 발효기간과 효모균과 유산균 등의 미생물 균총의 변화가 영향을 미치는 것으로 보 고되고 있다(Yoon 등, 2010). 결과적으로 본 연구에서의 현 미발효식초의 총 유기산 함량은 발효 전 $1,017.34 \mathrm{mg} \%$ 에서 발효 16일차에 $6,663.46 \mathrm{mg} \%$ 로 크게 증가하였다.

현미발효식초의 발효기간 중 유리아미노산의 함량 변화는 Table 4와 같다. 발효 전 현미발효식초의 유리아미노산의 총 함량은 $21.84 \mathrm{mg} \%(\mathrm{w} / \mathrm{v})$ 수준으로 glutamic acid, leucine, lysine, phenylalanine, alanine, proline, tyrosine, GABA가

Table 4. Changes in free amino acid contents $(\mathrm{mg} \%, \mathrm{w} / \mathrm{v})$ of brown rice vinegar during fermentation periods

\begin{tabular}{|c|c|c|c|c|c|}
\hline \multirow{2}{*}{ Free amino acid } & \multicolumn{5}{|c|}{ Fermentation time (day) } \\
\hline & 0 & 4 & 8 & 12 & 16 \\
\hline Leu & $1.97 \pm 0.01^{1) \mathrm{c} 2)}$ & $1.82 \pm 0.01^{\mathrm{b}}$ & $1.81 \pm 0.04^{\mathrm{b}}$ & $1.77 \pm 0.02^{\mathrm{ab}}$ & $1.70 \pm 0.06^{\mathrm{a}}$ \\
\hline Ile & $0.70 \pm 0.00^{\mathrm{b}}$ & $0.65 \pm 0.00^{\mathrm{ab}}$ & $0.67 \pm 0.03^{\mathrm{ab}}$ & $0.66 \pm 0.04^{\mathrm{ab}}$ & $0.62 \pm 0.02^{\mathrm{a}}$ \\
\hline Met & $0.43 \pm 0.01^{\mathrm{b}}$ & $0.40 \pm 0.01^{\mathrm{a}}$ & $0.38 \pm 0.01^{\mathrm{a}}$ & $0.37 \pm 0.00^{\mathrm{a}}$ & $0.38 \pm 0.02^{\mathrm{a}}$ \\
\hline Thr & $0.57 \pm 0.05^{\mathrm{a}}$ & $0.65 \pm 0.00^{\mathrm{a}}$ & $0.63 \pm 0.05^{\mathrm{a}}$ & $0.66 \pm 0.01^{\mathrm{a}}$ & $0.65 \pm 0.03^{\mathrm{a}}$ \\
\hline Phe & $1.35 \pm 0.00^{\mathrm{b}}$ & $1.29 \pm 0.00^{\mathrm{a}}$ & $1.27 \pm 0.00^{\mathrm{a}}$ & $1.25 \pm 0.01^{\mathrm{a}}$ & $1.24 \pm 0.04^{a}$ \\
\hline Lys & $1.52 \pm 0.01^{\mathrm{a}}$ & $1.50 \pm 0.02^{\mathrm{a}}$ & $1.50 \pm 0.01^{\mathrm{a}}$ & $1.48 \pm 0.01^{\mathrm{a}}$ & $1.48 \pm 0.04^{\mathrm{a}}$ \\
\hline His & $0.44 \pm 0.00^{\mathrm{a}}$ & $0.46 \pm 0.01^{\mathrm{a}}$ & $0.46 \pm 0.01^{\mathrm{a}}$ & $0.46 \pm 0.01^{\mathrm{a}}$ & $0.46 \pm 0.01^{\mathrm{a}}$ \\
\hline Gly & $0.66 \pm 0.00^{\mathrm{a}}$ & $0.66 \pm 0.01^{\mathrm{a}}$ & $0.66 \pm 0.01^{\mathrm{a}}$ & $0.65 \pm 0.01^{\mathrm{a}}$ & $0.63 \pm 0.01^{\mathrm{a}}$ \\
\hline Ser & $0.78 \pm 0.06^{\mathrm{b}}$ & $0.75 \pm 0.01^{\mathrm{ab}}$ & $0.69 \pm 0.06^{\mathrm{ab}}$ & $0.7 \pm 0.01^{\mathrm{ab}}$ & $0.68 \pm 0.01^{\mathrm{a}}$ \\
\hline Glu & $2.11 \pm 0.04^{\mathrm{d}}$ & $1.64 \pm 0.01^{\mathrm{c}}$ & $1.51 \pm 0.01^{\mathrm{b}}$ & $1.47 \pm 0.04^{\mathrm{ab}}$ & $1.43 \pm 0.04^{\mathrm{a}}$ \\
\hline Pro & $1.30 \pm 0.01^{\mathrm{e}}$ & $1.11 \pm 0.02^{\mathrm{d}}$ & $1.00 \pm 0.04^{\mathrm{c}}$ & $0.82 \pm 0.06^{\mathrm{b}}$ & $0.72 \pm 0.05^{\mathrm{a}}$ \\
\hline Tyr & $1.07 \pm 0.00^{\mathrm{a}}$ & $1.06 \pm 0.00^{\mathrm{ab}}$ & $1.06 \pm 0.00^{\mathrm{ab}}$ & $1.03 \pm 0.00^{\mathrm{a}}$ & $1.03 \pm 0.01^{\mathrm{a}}$ \\
\hline Ala & $1.31 \pm 0.02^{\mathrm{a}}$ & $1.58 \pm 0.05^{\mathrm{b}}$ & $1.57 \pm 0.01^{\mathrm{b}}$ & $1.55 \pm 0.02^{\mathrm{b}}$ & $1.52 \pm 0.05^{\mathrm{b}}$ \\
\hline Asn & $0.53 \pm 0.01^{\mathrm{a}}$ & $\mathrm{ND}^{3)}$ & ND & ND & ND \\
\hline Asp & $0.72 \pm 0.03^{\mathrm{a}}$ & ND & ND & ND & ND \\
\hline Arg & $0.17 \pm 0.01^{\mathrm{ab}}$ & $0.18 \pm 0.01^{\mathrm{b}}$ & $0.17 \pm 0.01^{\mathrm{ab}}$ & $0.17 \pm 0.01^{\mathrm{ab}}$ & $0.16 \pm 0.01^{\mathrm{a}}$ \\
\hline GABA & $1.00 \pm 0.01^{\mathrm{e}}$ & $0.85 \pm 0.02^{\mathrm{d}}$ & $0.77 \pm 0.01^{\mathrm{c}}$ & $0.67 \pm 0.04^{\mathrm{b}}$ & $0.47 \pm 0.04^{\mathrm{a}}$ \\
\hline Total amino acid & $21.84 \pm 0.34^{\mathrm{c}}$ & $20.07 \pm 0.19^{b}$ & $19.62 \pm 0.18^{\mathrm{ab}}$ & $19.24 \pm 0.08^{\mathrm{ab}}$ & $18.79 \pm 0.59^{\mathrm{a}}$ \\
\hline
\end{tabular}

${ }^{1)}$ Values are mean $\pm \mathrm{SD}(\mathrm{n}=2)$.

${ }^{2)}$ Different lower-case letters $\left({ }^{\mathrm{a}-\mathrm{e}}\right)$ in the same row indicate a significant difference according to Duncan's multiple test $(\mathrm{p}<0.05)$.

${ }^{3)} \mathrm{ND}$ is an abbreviation for not detected. 
$1.00-2.11 \mathrm{mg} \%$ 로 비교적 높은 함량을 나타내었다. Joo 등 (2009)은 누룩을 사용하여 발효시킨 현미발효식초에서 glutamic acid, alanine, proline, tyrosine, leucine이 높은 함량 을 보였다고 보고하여 본 연구결과와 유사한 경향을 보였다. 그러나 본 연구에서 사용된 발효식초는 초산발효가 진행되면 서 leucine, isoleucine, phenylalanine 등의 필수아미노산과 glutamic acid, proline, aspartic acid, GABA 등의 비필수 아 미노산 함량이 감소하였다. 특히, 16 일간 발효한 현미발효식 초의 유리아미노산 함량은 $18.79 \mathrm{mg} \%$ 이었으며, 이는 시판 현미식초의 유리아미노산 함량과 비슷한 수준이었다(Jeong 등, 1998). 또한, 초산발효에 의해 유리아미노산 함량이 발효 0 일차 $21.84 \mathrm{mg} \%(\mathrm{w} / \mathrm{v})$ 에서 발효 16 일차 $18.79 \mathrm{mg} \%(\mathrm{w} / \mathrm{v})$ 로 감소하였는데, 이는 산도의 증가로 인한 산성아미노산의 탈 탄소와 lysine 등 Maillard 반응에 관여하는 아미노산의 감소 에 의한 것으로 추정된다.

\section{세포독성 확인}

현미발효식초 추출물의 지방분화 억제효과 평가에 앞서 시료가 3T3-L1에 미치는 독성 여부를 판단하기 위해 CCK-8 assay를 이용하여 세포독성을 확인한 결과는 Fig. 1과 같다. $\mathrm{BRV}$ 0d와 BRV $16 \mathrm{~d}$ 시료 모두 $400 \mu \mathrm{g} / \mathrm{mL}$ 의 농도에서 $60 \%$ 이하의 세포생존율을 보였지만, $50-100 \mu \mathrm{g} / \mathrm{mL}$ 의 농도구간에 서는 $80 \%$ 이상의 생존율을 보여 세포독성을 유발하지 않음 을 확인하였다. 이러한 결과를 바탕으로 세포독성이 유발되 지 않는 $100 \mu \mathrm{g} / \mathrm{mL}$ 이하의 농도에서 지방분화 억제효과 실 험을 진행하였다.

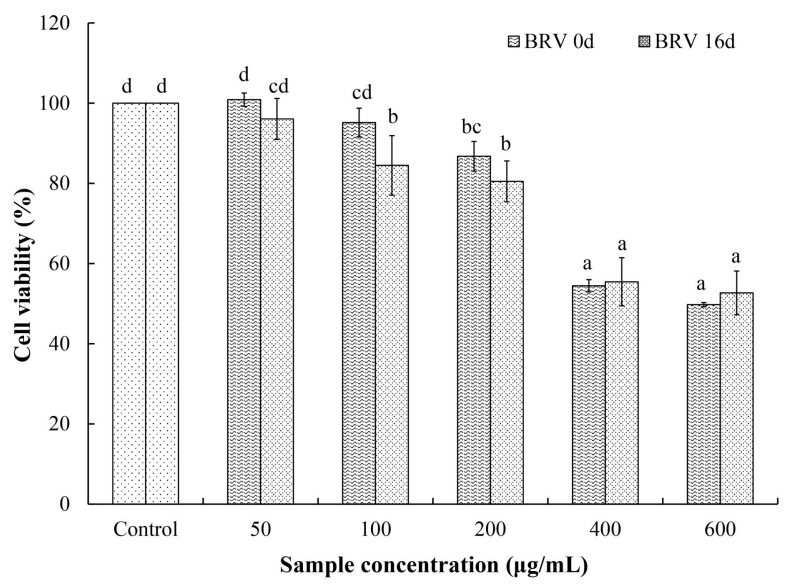

Fig. 1. Effect of brown rice vinegar on cell viability in 3T3-L1 preadipocytes.

Error bar indicates the SD of the mean, and means with the same letter are not significantly different according to Duncan's multiple range test $(\mathrm{p}<0.05)$. BRV 0d, 16d are the day 0, 16 of fermentation of brown rice vinegar.

\section{지방분화 및 렙틴생성 억제효과}

현미발효식초 추출물의 지방분화 억제효과를 평가하기 위 해 Oil-Red-O staining을 진행한 결과는 Fig. 2 와 같다. 지방분 화 유도제인 $\mathrm{MDI}$ 를 처리하여 8 일 동안 지방전구세포를 분화 한 결과, 지방구의 형성이 이루어진 것을 현미경 상으로 관찰 하였다(Fig. 2A). 또한 현미발효식초 추출물(BRV 0d과 BRV $16 \mathrm{~d})$ 을 처리함에 따라 지방구의 크기와 개수가 감소하였고, 처리농도 의존적으로 중성지질의 염색 정도가 감소하여 현미 발효식초 추출물의 분화 억제효과를 확인하였다. Oil-Red-O 시약이 염색된 지방구를 isopropyl alcohol에 용출시켜 흡광 도를 측정하였을 때, 모든 시료 처리구에서 농도 의존적으로 중성지질 축적이 감소함을 보였다(Fig. $2 \mathrm{~B}$ ). 특히 BRV $16 \mathrm{~d}$ 추출물 $50,100 \mu \mathrm{g} / \mathrm{mL}$ 처리농도에서 중성지질 축적률이 각 각 $82.0 \%, 72.2 \%$ 로 측정되어 농도 의존성을 보였다.

렙틴은 지방조직에서 분비되는 호르몬으로 식욕조절 중추 인 시상하부에 작용하여 식욕을 길항적으로 조절한다(Halas 등, 1997). 대다수의 비만인은 혈중 렙틴 농도가 일반인보다 높은 수준으로 나타나 렙틴은 비만 유전자 단백산물로 여겨 진다(Zhang 등, 1994). In vitro 상의 3T3-L1 지방 전구세포 에서도 지방축적이 유도될 때 렙틴의 분비가 비례하여 증가 한다는 연구결과(Havel, 2000)로 보아 렙틴은 비만 억제효과 를 판단하는 지표로 사용될 수 있다. 본 연구에서 3T3-L1 지 방전구세포에 현미식초 추출물(BRV 0d과 BRV 16d)을 처리 하여 분화유도 8 일 경과 후 배지에 분비된 렙틴 단백질을 정 량한 결과(Fig. 2C), 비처리구의 렙틴 단백질 발현량은 1.04 $\mathrm{ng} / \mathrm{mL}$ 수준이었으며, 현미식초 추출물을 처리함에 따라 $50 \%$ 이상 감소하는 경향을 보였다. 그러나 각 추출물의 농도 의존적 경향은 $50 \mu \mathrm{g} / \mathrm{mL}$ 이상의 처리농도에서 유의차를 보 이지 않았고, 발효 일차에 따른 차이가 없어 초산발효에 의한 영향보다는 현미발효식초 에탄올추출물에 함유된 성분의 렙 틴생성 저해효과라고 판단된다.

\section{지방분화 transcription factor 발현 확인}

현미발효식초 추출물에 의한 항비만 효과가 지방생성의 억제로부터 유도되는지를 확인하기 위하여 지방세포의 지방 생성 관련 유전자 발현량을 확인하였다(Fig. 3). 지방 전구세 포는 lipogenesis 과정을 통해 지방분화가 유도되어 지방구를 형성하게 된다. 이러한 lipogenesis 과정에서 PPAR $\gamma$ 는 dexamethasone의 처리에 의해 지방분화 초기에 발현되는데 지방세 포 분화와 지방산 대사조절에 중요한 기능을 담당한다(Kim과 Park, 2002). 본 연구에서 BRV 16d 시료를 $100 \mu \mathrm{g} / \mathrm{mL}$ 처리하 였을 때, 8 일 동안 지방분화가 완료된 대조구에 비해 PPAR $\gamma$ 는 $81.3 \%$ 로 유의적으로 감소하였다(Fig. $3 \mathrm{~B}$ ). SREBP는 콜레 스테롤 대사와 지방산 대사에 관여하는 유전자들의 발현을 조 
(A)

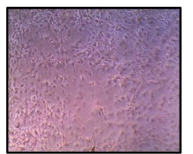

MDI (-)

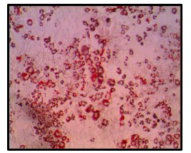

MDI (+)

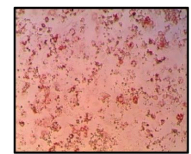

EGCG
$(100 \mu \mathrm{M})$

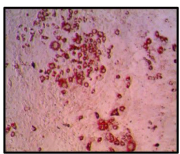

BRV Od

$(50 \mu \mathrm{g} / \mathrm{mL})$

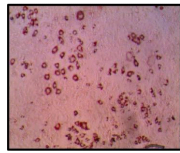

BRV Od

$(100 \mu \mathrm{g} / \mathrm{mL})$

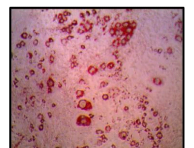

BRV 16d

$(50 \mu \mathrm{g} / \mathrm{mL})$

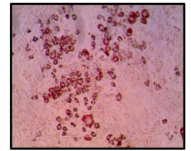

BRV 16d

(B)

(C)
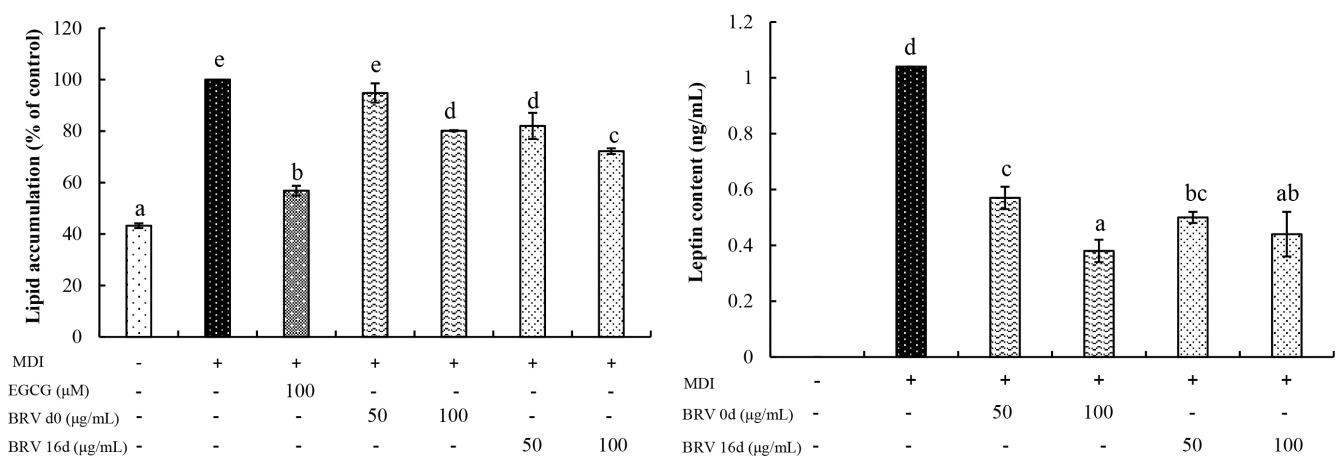

Fig. 2. Inhibitory effect of brown rice vinegar on adipocyte differentiation (A) and the lipid accumulation (B) and leptin secretion (C) in 3T3-L1 preadipocyte.

Adipocyte differentiation is microscopiic observation of lipid droplets stained with Oil-Red-O. Error bar indicates the SD of the mean, and means with the same letter are not significantly different according to Duncan's multiple range test ( $<0.05$ ). BRV 0d, $16 \mathrm{~d}$ are the day 0,16 of fermentation of brown rice vinegar. EGCG is positive control and was analyzed at a concentration of $100 \mu \mathrm{M}$.

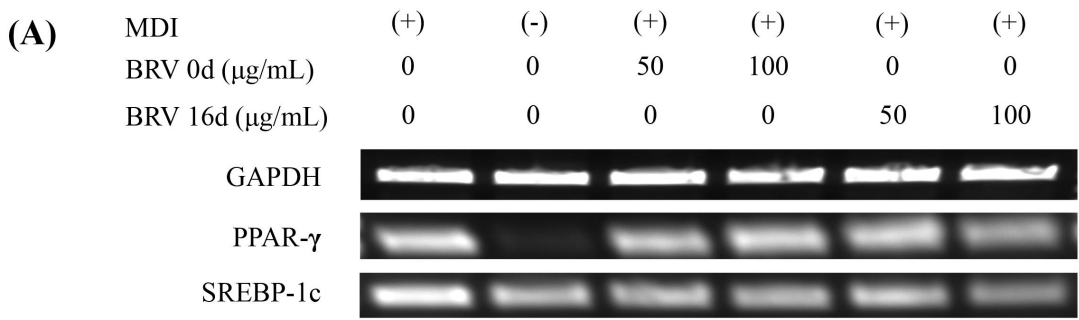

(B)

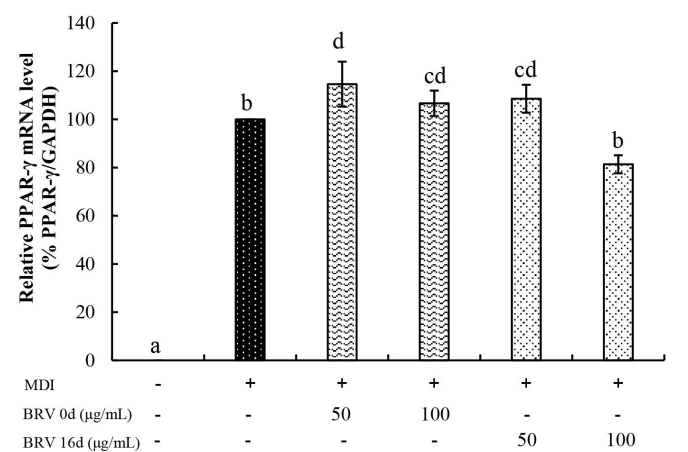

\section{(C)}

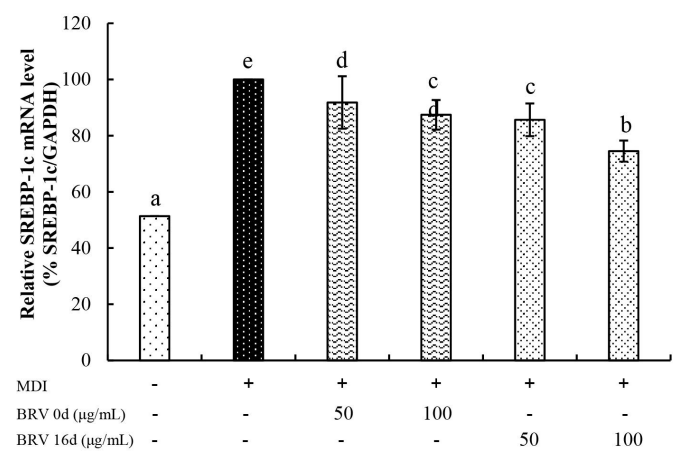

Fig. 3. Effect of brown rice vinegar on lipogenesis-related gene expression in 3T3-L1 adipocytes.

The mRNA expressions of PPAR $\gamma$ (B) and SREBP-1c (C) were determined by RT-PCR analysis (A). Error bar indicates the SD of the mean, and means with the same letter are not significantly different according to Duncan's multiple range test ( $<<0.05$ ). BRV 0d, 16d is day 0, 16 of fermentation of brown rice vinegar. 
절하는 전사인자로 알려져 있고(Brown과 Goldstein, 1997), SREBP-1c는 지방산 대사와 lipid의 생합성에 관여한다. 즉, $\mathrm{ADD} 1 / \mathrm{SREBP} 1 \mathrm{c}$ 를 지방전구세포에서 과발현시킬 경우 PPAR $\gamma$ 유전자의 발현을 촉진하여 결과적으로 지방 세포의 분화를 촉진하는 것으로 알려져 있다(Kim 등, 1998). 본 연구에서 분화유도제(MDI) 처리에 따라 비처리구 대비 SREBP-1c 발 현량이 $50 \%$ 이상 증가하였고(Fig. $3 \mathrm{C}$ ), 시료 처리농도 증가에 따라 발현량이 유의적으로 감소하였다. 특히 BRV $16 \mathrm{~d}$ 시료 처리농도 $50 \mu \mathrm{g} / \mathrm{mL}$ 에서 $85.6 \%, 100 \mu \mathrm{g} / \mathrm{mL}$ 에서 $74.5 \%$ 로 감 소하여 농도 의존적으로 유의적 효과를 나타내었다. 이와 같 은 결과로 현미발효식초 추출물 처리에 따라 지방세포에서 분화정도를 조절하는 PPAR $\gamma$ 와 SREBP-1c 발현량이 감소하 였고, 일정 농도 수준에서는 발효가 완료된 BRV $16 \mathrm{~d}$ 시료 에서 유의적으로 감소되어 그 효과를 확인하였다. 따라서 현 미발효식초 추출물이 지방 전구세포에 지방분화 관련 전사 인자의 발현량을 감소시켜 항비만 효과를 보이는 것으로 판 단된다.

\section{요 약}

현미를 주원료로 하여 누룩과 효모를 이용하여 현미주를 제조하였고, Acetobacter pasteurianus JBA172705 균주를 적 용하여 종초를 제조하였다. 현미주의 알코올 농도는 $6 \%$ 로 조정하여 종초를 $10 \%$ 첨가하였고, 16 일 동안 진탕배양 $\left(30^{\circ} \mathrm{C}\right.$, $120 \mathrm{rpm}$ )하여 발효기간에 따른 발효특성을 분석하였다. 또한 초산발효 16 일차 시료를 $70 \%$ 에탄올 추출하여 $3 \mathrm{~T} 3-\mathrm{L} 1$ 지방 전구세포를 이용한 항비만 효과를 평가하였다. 현미발효식초 는 발효 16 일 후 총산도가 $6.43 \%$ 로 증가하였고, 유기산 중 acetic acid가 15배, succinic acid가 2.5배 이상 증가하였다. 총페놀성 함량과 유리아미노산 함량은 초산발효기간 동안 감 소하여 발효 16 일차에 각각 $48.53 \mathrm{mg} \mathrm{GAE} / \mathrm{mL}$ 와 18.79 $\mathrm{mg} \%(\mathrm{w} / \mathrm{v})$ 였다. 현미식초 발효 16 일차 추출물을 $3 \mathrm{~T} 3-\mathrm{L} 1$ 지 방전구세포에 $50,100 \mu \mathrm{g} / \mathrm{mL}$ 의 농도로 처리하였을 때, 농도 의존적으로 지질축적률이 감소하여 $100 \mu \mathrm{g} / \mathrm{mL}$ 처리농도에 서 지질축적률은 $72.2 \%$ 였다. 렙틴 농도는 비처리구에 비해 $50 \%$ 이상 감소하였지만 농도 의존적인 유의차는 없었다. 지 방분화 전사인자인 PPAR $\gamma$ 과 SREBP-1c 발현량은 BRV $16 \mathrm{~d}(100 \mu \mathrm{g} / \mathrm{mL})$ 처리 시 비처리구에 비해 각각 $81.35 \%$ 와 $74.5 \%$ 로 감소하였다. 결과적으로 현미식초 추출물인 $\mathrm{BRV}$ $16 \mathrm{~d}$ 의 항비만 효과는 지질축적을 억제하고 지방분화 전사인 자의 발현을 감소시키기에 효과적일 것으로 기대된다.

\section{감사의 글}

본 논문은 농림축산식품부 향토산업 육성사업(과제명: 친
환경 쌀 융복합 고부가 제품개발, MIFI 2019-1)의 연구비 지 원으로 이루어졌으며, 이에 감사드립니다.

\section{Conflict of interests}

The authors declare no potential conflict of interest.

\section{ORCID}

Eun Ah Sim https://orcid.org/0000-0003-2859-0738

Young-Soo Kim https://orcid.org/0000-0003-1308-4453

\section{References}

Baek CH, Choi JH, Choi HS, Jeong ST, Kim JH, Jeong YJ, Yeo SH. Quality characteristics of brown rice Makgeolli produced under differing conditions. Korean J Microbiol Biotechnol, 41, 168-175 (2013)

Brown MS, Goldstein JL. The SREBP pathway: Reglulation of cholesterol metabolism by proteolysis of a membranebound transcription factor. Cell, 89, 331-340 (1997)

Chio EJ, Kim HK, Park HS. Effect of Orlistat on the metabolic syndrome in obese patients. Korean J Obes, 15, 159-167 (2006)

Fushimi T, Suruga K, Oshima Y, Fukiharu M, Tsukamoto Y, Goda T. Dietary acetic acid reduces serum cholesterol and triacylglycerols in rats fed a cholesterol-rich diet. $\mathrm{Br}$ J Nutr, 95, 916-924 (2006)

Halaas JL, Boozer C, Blair-West J, Fidahusein N, Denton DA, Friedman JM. Physiological response to long-term peripheral and central leptin infusion in lean and obese mice. Proc Natl Acad Sci USA, 94, 8878-8883 (1997)

Havel PJ. Role of adipose tissue in body-weight regulation: Mechanisms regulating leptin production and energy balance. Proc Nutr Soc, 59, 359-371 (2000)

ISO 14502-1. Determination of Substances Characteristic of Green and Black Tea-Part 1: Content of Total Polyphenols in Tea-Colorimetric Method Using Folin-Ciocalteu Reagent. International Organization for Standardization, Geneva, Switzerland (2005)

Jeong YJ, Lee MH. A view and prospect of vinegar industry. Food Industry and Nutrition, 5, 7-12 (2000)

Jeong YJ, Soe JH, Jung SH, Shin SR, Kim KS. The quality comparison of uncleaned rice vinegar by two stages 
fermentation with commercial uncleaned rice vinegar. Korean J Food Preserv, 5, 374-379 (1998)

Jeong YJ. Current trends and future prospects in the Korean vinegar industry. Food Science and Industry, 42, 52-59 (2009)

Joo KH, Cho MH, Park KJ, Jeong SW, Lim JH. Effect of fermentation method and brown rice content on quality characteristics of brown rice vinegar. Korean J Food Preserv, 16, 33-39 (2009)

Karamadoukis L, Shivashankar GH, Ludeman L, Williams AJ. An unusual complication of treatment with orlistat. Clin Nephrol, 71, 430-432 (2009)

Kawaguchi T, Osatomi K, Yamashita H, Kabashima T, Uyeda K. Mechanism for fatty acid 'sparing' effect on glucose induced transcription: Regulation of carbohydrateresponsive element-binding protein by AMP-activate protein kinase. J Biol Chem, 277, 3829- 3835 (2002)

KFDA. Food Code. Korea Food and Drug Administration. p 5-21 (2012)

Kim DS, Shin KS. Chemical property and macrophage stimulation activity of polysaccharides isolated from brown rice and persimmon vinegars. Korean J Food Nutr, 27, 1033-1042 (2014)

Kim JB, Park JY. Molecular insights into fat cell differentiation and functional roles of adipocytokines. Endocrinol Metab, 17, 1-9 (2002)

Kim JB, Wright HM, Wright M, Spiegelman BM. ADD1/ SREBP1 activates PPAR $\gamma$ through the production of endogenous ligand. Proc Natl Acad Sci USA, 95, 43334337 (1998)

Kim YS, Song GS. Characteristics of kiwifruit-added traditional Kochujang. Korean J Food Sci Technol, 34, 1091-1097 (2002)

Lee HB, Oh HH, Jun HI, Jeong DY, Song GS, Kim YS. Functional properties of tomato vinegar manufactured using Makgeolli seed culture. J Korean Soc Food Sci Nutr, 47, 904-911 (2018)

Lee SJ, Kim JH, Jung YW, Park SY, Shin WC, Park CS, Hong SY, Kim GW. Composition of organic acids and physiological functionality of commercial Makgeolli. Korean J Food Sci Technol, 43, 206-212 (2011)

Lee SW, Kwon JH, Yoon SR, Woo SM, Jang SY, Yeo SH, Choi JH, Jeong YJ. Quality characteristics of brown rice vinegar by different yeasts and fermentation condition. J Korean Soc Food Sci Nutr, 39, 1366-1372 (2010)

Sim EA. A study on fermentation characteristics, functionality and storage conditions of natural fermented brown rice vinegar. MS Thesis. Jeonbuk National University, Korea, p 23-24 (2020)

Yoon SR, Kim GR, Lee JH, Lee SW, Yeo SH, Jeong YJ, Kwon JH. Properties of organic acids and volatile components in brown rice vinegar prepared using different yeasts and fermentation methods. Korean J Food Preserv, 17, 733-740 (2010)

Zebisch K, Voigt V, Wabitsch M, Brandsch M. Protocol for effective differentiation of 3T3-L1 cells to adipocytes. Anal Biochem, 425, 88-90 (2012)

Zhang Y, Proenca R, Maffei M, Barone M, Leopold L, Friedman JM. Positional cloning of the mouse obese gene and its human homologue. Nature, 372, 425-432 (1994) 